\title{
Land-use and Land-cover Changes in Pastoral Drylands: Long-term Dynamics, Economic Change, and Shifting Socioecological Frontiers in Baringo, Kenya
}

\author{
Clemens Greiner $^{1}$ D $\cdot$ Hauke-Peter Vehrs ${ }^{1} \cdot$ Michael Bollig $^{1}$
}

Accepted: 30 August 2021 / Published online: 20 September 2021

(c) The Author(s) 2021

\begin{abstract}
The ongoing fragmentation of pastoral drylands is a matter of concern throughout Africa. Using the example of rangelands in northern Baringo County, Kenya, that were under uniform pastoral use until the late twentieth century, we trace land-use and land-cover changes (LULCCs) since the 1980s. Based on ethnographic, historical, and remote sensing data, we show how bush encroachment and dryland farming have led to the increasing modification and conversion of formerly open rangelands and the diversification of livelihoods. These LULCC dynamics are related to and driven not only by internal processes of socioeconomic change (e.g., sedentarization, changing rangeland management practices, growing markets for small stock, increasing stratification and cultural differentiation) but also by ecological processes such as wildlife defaunation and ecological invasions. Based on our findings, we suggest that a socioecological approach to Kopytoff's notion of the internal African frontier can be helpful in framing these LULCC-related dynamics.
\end{abstract}

Keywords Pastoralism $\cdot$ Pokot $\cdot$ Land-use and land-cover changes $\cdot$ Frontiers $\cdot$ Baringo County $\cdot$ Kenya

\section{Introduction and Background}

Drylands are the most dominant land cover on earth and support the livelihoods of large numbers of people. At the same time, they are highly susceptible to risks of environmental degradation and climatic perturbation and, increasingly, to the manifold consequences of global climate change (Boone et al. 2018; Engler et al. 2018; Galvin 2021). Environmental degradation and climate change, growing human populations, resource extraction, and other developments have wrought increasing detrimental land-use and landcover changes (LULCCs) with serious consequences for the food security and livelihoods of local populations (Galvin et al. 2008; Reid et al. 2014). In view of these massive changes, developing a better understanding of the complex linkages between environmental changes and the changing livelihood strategies of rural communities is necessary. This research is of especial relevance to populations

Clemens Greiner

clemens.greiner@uni-koeln.de

1 Universität zu Köln, Albertus-Magnus-Platz, 50923 Köln, Germany depending predominantly on pastoralist livelihoods. Traditional livestock-based economies have proven to be particularly vulnerable in recent processes of change, not least because of their historical marginalization and notoriously insecure access to land (Krätli 2019; Gabbert et al. 2021; Lind et al. 2020a). While many contributions have focused primarily on the impact of externally imposed changes, such as state interventions and resource or land grabbing resulting from large-scale investments (e.g., Mosley and Watson 2016; Lind et al. 2020b), we concur with Petersen et al. (2021), who hold that current changes "are driven by local as well as external anthropogenic and ecological factors." With this study, we also address the need for more longitudinal studies that track socioecological changes over time (Lind et al. 2020a: 12). The complex processes underlying the fragmentation of pastoral drylands can be analyzed meaningfully only in an interdisciplinary effort combining social science and natural science approaches both of which should take historical information into account.

Focusing on the drylands in Baringo, Kenya, and more precisely on the rangelands of Tiaty East (formerly East Pokot), our study provides insights into the LULCC dynamics and socioeconomic dimensions over a period of more than 30 years. Remotely sensed 
data (1985-2015) show that major changes in land use are connected to a rapid transition to maize cultivation, whereas land-cover changes are associated mostly with the increase in dense shrubs and a concomitant gradual loss of open grassland. These data concur with dense descriptions of this transition by cultural insiders. Informants provided a vivid picture of bush encroachment and land-use transitions. We can trace the agency of local people in these changes, and their response to them challenges a fundamental assumption in the ethnographic literature on East African pastoralism, namely, that crop farming by outsiders has encroached on key pastoral resources (Galaty and Bonte 1991; Spencer 1998; Markakis 2004; Abbink et al. 2014).

While we do not question whether such expansions of either small-scale agricultural land use or large corporate, high-modernist agrarian schemes onto the pastures of herding populations actually do occur (Reid et al. 2004; Gabbert 2021), our data suggest a different type of process: whereas a constantly growing number of people in our research area who previously relied on pastoral livelihoods have resorted to crop farming (and thus contributed to land-use change), others remain firmly embedded in pastoral strategies. Rather than the neo-Malthusian encroachment scenario evoked by Spencer and others, we suggest that a socioecological view of Kopytoff's notion of the internal African frontier (Kopytoff 1987) can explain the territorial shifts between ecological processes, population dynamics, and production strategies that accompany large-scale LULCCs without falling into a geodeterministic trap.

Our objectives in this study are threefold. We provide a concise, longitudinal analysis of the LULCCs in Tiaty East (Baringo, Kenya). Furthermore, we examine both the environmental and socioeconomic factors that have contributed to these changes as well as their interplay. Finally, we suggest a conceptual approach to interpret the observed socioecological dynamics.

We first introduce the study area and our methodological approaches before describing major LULCCs brought about by bush encroachment and farming. We then analyze the consequences of rangeland modification before relating our findings to notions of frontier dynamics in a concluding discussion.

\section{Study Area}

Our study region is in the Lake Baringo basin in the central Rift Valley of Kenya and the adjacent eastern highlands towards the Laikipia Plateau (Fig. 1). Formerly known as East Pokot District, Tiaty East Subcounty is part of Baringo County. It comprises approximately 4,500 $\mathrm{km}^{2}$ and has an estimated population of $80,000-105,000$ (Vehrs forthcoming). ${ }^{1}$ Climatologically, the area is classified as semiarid with temperate to warm temperatures and is prone to recurrent droughts (cf. Agro-climatic Zone Map of Kenya by Sombroek et al. 1982). Vegetation is dominated by acacia bush savannah, and the topography is rugged and characterized by lowland plains, rolling hills, and mountain ranges. ${ }^{2}$ East Pokot is inhabited almost exclusively by Nilotic-speaking Pokot people. Specialized pastoralism has been the dominant form of land use across almost the entire area for the past 200 years. Bollig and Anderson have extensively described the historical dynamics of the emergence and consolidation of this specialized pastoralism (Bollig 1992, 2006, 2016) and the wider Baringo area (Anderson 2002, 2016). During neither colonial nor postcolonial times was the current territory of East Pokot/Tiaty the target of land expropriation by outsiders, whether colonialists, agriculturalists, or immigrants from other parts of the country. East Pokot District (present-day Tiaty East) did not participate in the group ranch programs of the 1970s and 1980s, which profoundly changed land use in the Maasai- and Samburu-dominated rangelands in southern Kenya and north-central Kenya (Galaty 1994). Attempts to implement wildlife conservation - which were detrimental to other pastoral areas in East Africa (Brockington 2002) - started only in the early 2000s and met with fierce resistance (Greiner 2012). Since about 2015 , the area has attracted massive investments in geothermal energy production and related infrastructure development (Greiner 2020; Greiner et al. 2021; Klagge et al. 2020).

\section{Data and Methods}

Our research is inspired by approaches that combine ethnographic data with remote sensing and insights from other disciplines in the analysis of long-term LULCCs (Casimir and Rao 1998; Jiang 2003; Campbell et al. 2005; Guyer et al. 2007). Building on decades of fieldwork in the area, on the systematic classification of satellite images, on data from interdisciplinary field research and on historical ecology, we are present a comprehensive analysis of LULCCs covering a period of 30 years and

\footnotetext{
${ }^{1}$ Official estimates are currently over 153,000 (KNBS 2019: 26). Although the background for the extreme fluctuations is open to discussion (counting pastoral groups is generally very difficult and may be based on incorrect extrapolations), there is hardly any concrete indication of what population figures in fact are.

2 For more information on the geobiophysical situation, see Vehrs and Heller (2017) and Greiner et al. (2013).
} 


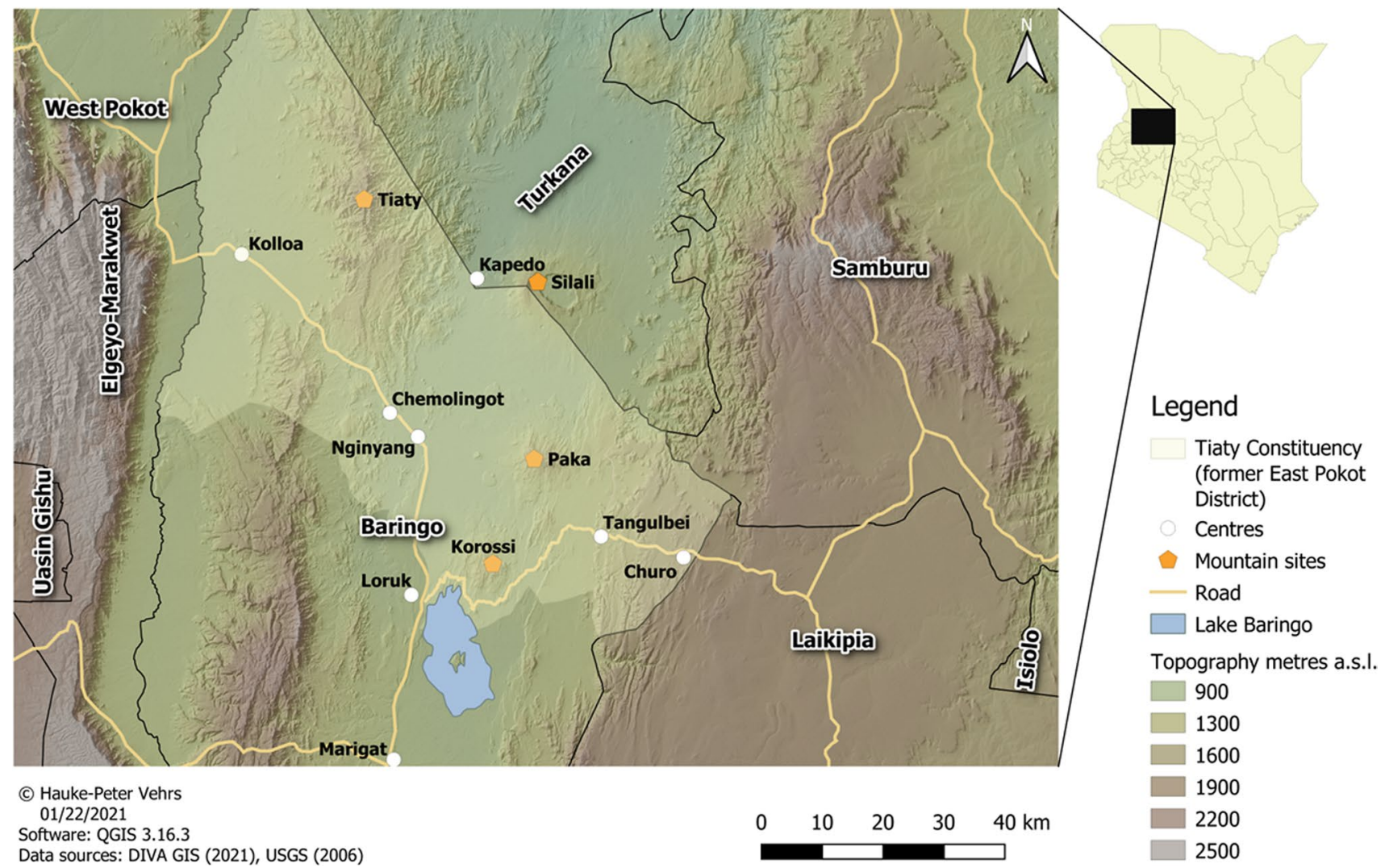

Fig. 1 Study region

beyond. Our ethnographic data stretch from the late 1980s to the present (Bollig et al. 2014; Vehrs 2016) and include recurrent interdisciplinary field campaigns with agronomists and botanists (Bollig and Schulte 1999; Greiner et al. 2013; Becker et al. 2016; Vehrs and Heller 2017). Our analysis also builds on studies based on remote sensing, which include time series of Landsat images for the period 1985 to 2015 (Obermaier 2013; Basukala et al. 2019a, b). Bollig has worked in the area extensively since 1987 and has made intermediate restudy visits (Bollig 2006). Österle started ethnographic fieldwork in 2003 (Österle 2008), Greiner in 2010, and Vehrs in 2013. In recent decades, grants for research units and collaborative research centers funded by the German Research Foundation (DFG) have facilitated joint field visits and interdisciplinary research campaigns. ${ }^{3}$ These include a recent household survey that covered not only Tiaty East but also other areas in Kenya, Zambia, Namibia, and Tanzania (Nshakira-Rukundo et al. 2019). ${ }^{4}$

\footnotetext{
${ }^{3}$ RU 1501 Resilience, Collapse and Reorganisation, SFB/TRR 228 Future Rural Africa.

${ }^{4}$ See https://www.trr228db.uni-koeln.de/site/index.php.
}

\section{Results}

Before we describe three major LULCC dynamics, we present a historical overview of vegetation changes of the past c. 200 years - the quantitatively most dominant form of LULCC. We then describe more recent bush encroachment dynamics and the spread of crop farming. Comparing these two processes, we analyze the modification of rangelands and the diversification of land use before discussing the socioeconomic implications of these changes in more detail.

\section{LULCC Background in the Study Area}

In the mid-eighteenth and early nineteenth centuries, a period of extreme drought hit the wider Baringo-Bogoria basin (see, e.g., Bessems et al. 2008; Kiage and Liu 2009). This "Great Catastrophe" (Anderson 2016: 46) contributed to the desiccation of Lake Baringo. From the 1830s onwards, the lake was replenished, and various groups settled around it and in the wider region. This assumption is supported by an increase in pollen and spores in the sediments of Lake Baringo after the 1830s as evidence of vegetational change and increased human activity. Kiage and Liu (2009) discuss 
the results of their paleoenvironmental analysis of sediment cores from Lake Baringo against the background of landcover change in the Baringo region and show that prior to AD 1650, the region experienced conditions of high aridity, as is also reflected in low wildlife numbers (and corresponding fungal spores in the cores). In the subsequent period up to AD 1750, conditions improved again. Although human influence cannot be definitively proven, the occurrence of large wild herbivore populations has been identified, including elephants, rhinoceroses, hippopotamuses, and different kinds of ungulates. This period was followed by another phase of intense drought, which led to a collapse of recorded fungal spores, indicating drastically declining herbivore populations. Furthermore, larger amounts of charcoal found during this period up to AD 1830 indicate a time of extreme drought, eventually leading to the desiccation of Lake Baringo. After AD 1830, the climate shifted again, and a wetter period began that also had an identifiable effect on local livelihoods. There was an increase in microscopic charcoal in the paleoenvironmental records after AD 1830 that Kiage and Liu (2009) link to human influences such as the burning of biomass for agriculture or the burning of pastures for tick control. For the Pokot north of Lake Baringo, this was the beginning of a period of pastoral specialization (Bollig and Österle 2013) and the buildup of large cattle herds. Notably, periodic changes in both climate and vegetation took place over a long period of time, and oscillating evidence for different concentrations of pollen (tree and grass species) and spores can be found. Bollig $(2006,2016)$ reports that even the major disasters of the late nineteenth century (rinderpest, drought in the 1890s) did not profoundly interrupt this period of pastoral specialization, which was characterized by highly beneficial human/livestock ratios, mobility, and open access to rangelands within a wide ethnically defined territory and the absence of other, e.g., agricultural, land-use patterns in the wide plains north of Lake Baringo.

The growing human impact on the environment became particularly evident at the beginning of the twentieth century. Accounts of the early explorers reveal the extensive grasslands of the area and the abundance of wildlife (see, among others, Thomson 1887; Hobley 1906; Dundas 1911). Whereas wildlife numbers decreased rapidly due to European and indigenous big-game hunts conditioned by the strong international demand for ivory in the late nineteenth and early twentieth centuries (Chapman 1908; Dickinson 1908; Somerville 2016), land-cover changes took place at a slower pace and with some delayed effects. The hunting of wild animals, especially by European big-game hunters, led to the almost complete depletion of large herbivore populations by the 1940s (Little 1996). This defaunation and the concomitant buildup of large cattle herds resulted in a radical restructuring of landscape agents and the absence of their impacts on the ecosystem (e.g., through lack of browsing, trampling effects, elephant damage). It also led to a gradual change in the grass-dominated savannah of that time (see, e.g., Pringle et al. 2011).

Archival material from the 1960s indicates that the grazing situation for livestock had already become strained because many regions with good pastureland were overgrazed (Edmondson 1965). However, the absence of grasses impacted not only the grazing but also the rangeland management, which relied on the regeneration of pasture by using fire to burn off parched grasses and foster new growth. Without combustible material, which was essential for high-intensity fires (which also limit the establishment of small trees), and with increasing human populations and the associated expansion into previously unpopulated areas, it became increasingly difficult to use fire for rangeland management (for the case of Pokot, see also Boonman 1993). These major changes in landscape composition (the defaunation of wildlife, increasing stocking rates, and the decay of the rangeland management system) led to incremental changes in the land cover during the twentieth century, as Vehrs and Heller (2017) illustrate for overall vegetation patterns and Bollig and Schulte (1999) for the grass cover. These processes of rangeland degradation intensified considerably towards the end of the twentieth century.

The first Landsat data analysis, comparing a time segment from 1973 to 1978, came from Conant (1982). His analysis reveals that in the Masol plains in the adjacent region of West Pokot, $20 \mathrm{~km}^{2}$ out of a study area of $69 \mathrm{~km}^{2}$ changed from bush-grassland to bushland. Due to local conflicts, herders were absent during the time of analysis, and Conant points out that this led to an enduring underutilization of the pastures. ${ }^{5}$ The major land-cover change Conant found was that grasslands rapidly turned into bushlands. His ground truthing reveals that in many underutilized ranges in the Pokot-Turkana borderlands, former grasslands had become Vachellia reficiens- and Senegalia mellifera-dominated bushlands that were of little use for cattle husbandry. At the same time, studies on highly utilized ranges in the Nginyang/ Paka area reveal similar vegetation changes. Additionally, where ranges had been permanently overutilized by large herds of cattle and small stock, bushlands expanded at the cost of grasslands (Saltlick 1991; Reckers 1992).

The analysis by Basukala et al. (2019a, b), on which most of our remotely sensed findings on land-cover change presented here rely, offers a larger-scale picture of land-cover changes between 1985 and 2015. The data cover more than $6,000 \mathrm{~km}^{2}$ in northern Baringo and southern Turkana

\footnotetext{
5 Conant (1982: 118) records a strong increase in bushland (covering $23.93 \%$ of the area in 1973 and $49.99 \%$ in 1978) and, at the same time, a strong decrease in the bush-grassland category (from $37.6 \%$ in 1973 to $13.04 \%$ in 1978 ).
} 
Counties and include five different categories of land cover: bare soil, dense shrubs and trees, shrub savannah, maize fields, and water bodies. Considering the total area under analysis, the two categories "bare soil" and "water bodies" show only slight fluctuations and will not be considered here. The following section, which addresses only the bush encroachment resulting from a constant increase in the category "dense shrubs and trees" at the gradual expense of "shrub savannah," is followed by an analysis of the category "maize fields," an LULCC that is of great importance for the region despite the relatively small area involved.

\section{Bush Encroachment}

In quantitative terms, the two categories "dense shrubs and trees" (with a closed canopy) and "shrub savannah" (mixed vegetation of shrubs, trees, and grasses and herbs) dominate the analyzed area (Table 1). Throughout the years surveyed, the two categories together cover a minimally unchanged average of $71.5 \%$ of the area surveyed. However, they show considerable and clearly pronounced changes on account of each other. Whereas the proportion of dense shrubs and trees was still approximately $15 \%$ in the mid-1980s, it rose steadily to over $30 \%$ of the total area in the mid-2010s. The opposite trend can be seen in the shrub savannah category, which has the largest proportion in 1985 , with almost $60 \%$ of the area, then decreases very sharply until 2005, and levels off at just under $40 \%$ of the area by 2015 . In total, over 1,100 $\mathrm{km}^{2}$ of shrub savannah was replaced almost entirely by the increase in dense shrubs and trees within only three decades, indicating a clear progression of bush encroachment in the area (for a similar observation in neighboring drylands in West Pokot County, see Petersen et al. 2021).

Within only three decades, one-sixth of the area changed from an open savannah to a dense bush savannah. This change is assessed similarly by many pastoral Pokot, who consider the changes of the last decades to be extensive and detrimental (Vehrs forthcoming). They see it as a time in which many grasses have disappeared and, moreover, many open savannah spaces have been encroached and covered by acacias. The ramifications of the incremental land-cover changes initiated in the early twentieth century have had tangible impacts on livestock husbandry and exert increasing pressure on cattle husbandry and on the remaining rangeland - especially through the lack of grazing land. This pressure is also visible in the fact that closures for dry-season forage storage can no longer be proclaimed, as they were in the past, because neighborhood councils are unable to argue that pasture must be preserved for the dry season when grazing land becomes scarce shortly after the end of the rainy season. Moreover, because rangeland management with fire cannot be implemented under current conditions (due to the
Table 1 Hectares and percentages of land cover in Tiaty/East Pokot, 1985-2015 (based on Basukala et al. 2019a, b)

\begin{tabular}{|c|c|c|c|}
\hline Year & Item & Total Hectar & $\begin{array}{l}\% \text { of classified } \\
\text { study area }\end{array}$ \\
\hline \multirow[t]{7}{*}{1985} & Unclassified & 1.44 & \\
\hline & Bare Soil & $163,121.67$ & $26.56 \%$ \\
\hline & Dense Shrubs and Trees & $91,712.16$ & $14.93 \%$ \\
\hline & Shrubs Savanna & $354,385.17$ & $57.70 \%$ \\
\hline & Maize Fields & $1,104.21$ & $0.18 \%$ \\
\hline & Water Bodies & $3,825.36$ & $0.62 \%$ \\
\hline & Sum & $614,150.01$ & \\
\hline \multirow[t]{7}{*}{1990} & Unclassified & 1.44 & \\
\hline & Bare Soil & $165,317.76$ & $26.92 \%$ \\
\hline & Dense Shrubs and Trees & $123,096.69$ & $20.04 \%$ \\
\hline & Shrubs Savanna & $320,491.44$ & $52.18 \%$ \\
\hline & Maize Fields & $1,914.57$ & $0.31 \%$ \\
\hline & Water Bodies & $3,328.11$ & $0.54 \%$ \\
\hline & Sum & $614,150.01$ & \\
\hline \multirow[t]{7}{*}{1995} & Unclassified & 1.44 & \\
\hline & Bare Soil & $193,257.45$ & $31.47 \%$ \\
\hline & Dense Shrubs and Trees & $116,242.47$ & $18.93 \%$ \\
\hline & Shrubs Savanna & $300,111.39$ & $48.87 \%$ \\
\hline & Maize Fields & 989.46 & $0.16 \%$ \\
\hline & Water Bodies & $3,547.80$ & $0.58 \%$ \\
\hline & Sum & $614,150.01$ & \\
\hline \multirow[t]{7}{*}{2000} & Unclassified & 1.44 & \\
\hline & Bare Soil & $162,940.23$ & $26.53 \%$ \\
\hline & Dense Shrubs and Trees & $180,027.63$ & $29.31 \%$ \\
\hline & Shrubs Savanna & $261,675.00$ & $42.61 \%$ \\
\hline & Maize Fields & $4,889.79$ & $0.80 \%$ \\
\hline & Water Bodies & $4,615.92$ & $0.75 \%$ \\
\hline & Sum & $614,150.01$ & \\
\hline \multirow[t]{7}{*}{2005} & Unclassified & 1.44 & \\
\hline & Bare Soil & $169,663.05$ & $27.63 \%$ \\
\hline & Dense Shrubs and Trees & $203,054.31$ & $33.06 \%$ \\
\hline & Shrubs Savanna & $231,223.77$ & $37.65 \%$ \\
\hline & Maize Fields & $5,937.48$ & $0.97 \%$ \\
\hline & Water Bodies & $4,269.96$ & $0.70 \%$ \\
\hline & Sum & $614,150.01$ & \\
\hline \multirow[t]{7}{*}{2010} & Unclassified & 1.44 & \\
\hline & Bare Soil & $154,573.83$ & $25.17 \%$ \\
\hline & Dense Shrubs and Trees & $212,063.94$ & $34.53 \%$ \\
\hline & Shrubs Savanna & $237,855.87$ & $38.73 \%$ \\
\hline & Maize Fields & $6,157.71$ & $1.00 \%$ \\
\hline & Water Bodies & $3,497.22$ & $0.57 \%$ \\
\hline & Sum & $614,150.01$ & \\
\hline
\end{tabular}


Table 1 (continued)

\begin{tabular}{llll}
\hline Year & Item & Total Hectar & $\begin{array}{l}\text { \% of classified } \\
\text { study area }\end{array}$ \\
\hline 2015 & Unclassified & 1.44 & \\
& Bare Soil & $158,946.30$ & $25.88 \%$ \\
& Dense Shrubs and Trees & $201,032.37$ & $32.73 \%$ \\
& Shrubs Savanna & $241,445.16$ & $39.31 \%$ \\
& Maize Fields & $8,176.14$ & $1.33 \%$ \\
& Water Bodies & $4,548.60$ & $0.74 \%$ \\
& Sum & $614,150.01$ & \\
\hline
\end{tabular}

lack of combustible material and the expansion of human settlements), bush vegetation cannot be kept under control.

The tree and bush species that have contributed notably to bush encroachment are Senegalia mellifera, Vachellia nubica, Vachellia reficiens, and Senegalia senegal, which, depending on the region, form dense stands. In most cases, undergrowth is entirely absent, which in turn impacts the availability of grass forage and thus cattle husbandry in general. The analysis by Basukala et al. (2019a, b) has much information about the quantity of land-cover changes but less about changes in the quality of forage. From the perspective of the pastoral Pokot, however, the answer is clear: not only has an extreme increase in bushes and trees occurred (most interviewees refer to the period between 1975 and 2014), but also various grass species have become locally extinct. In contrast, forage plant availability for browsers (goats and sheep) has increased considerably (Vehrs 2016). Pokot elders can recount with great accuracy the occurrences of different high-quality grass species in different locations in the past, and they unanimously emphasize that these grasses have become rare over time (Vehrs forthcoming).

However, the large-scale, long-term bush encroachment process is not the only land-cover change shaping the drylands in East Pokot. In recent decades, short-term ecological invasion processes have also contributed to changing land cover, though to a lesser extent than incremental acacia bush encroachment. Different invasive processes can be differentiated by their specific background (for further information, see Vehrs forthcoming). Prosopis juliflora has spread around Lake Baringo (Alvarez et al. 2019); Opuntia spp. are also present at Lake Baringo and are encroaching on grasslands in the Laikipia highlands (Muniappan et al. 2009; Zimmermann et al. 2009; Shackleton et al. 2017); and Dodonaea viscosa is spreading in the Pokot highlands around Churo (Becker et al. 2016). However, only the last is perceived by local informants as having a direct impact on local livelihoods in East Pokot, as it has overgrown vast areas of former rangeland that were previously available for grazing. Opuntia spp. and Prosopis juliflora, on the other hand, are very confined locally, especially at Lake Baringo, which makes access to water somewhat difficult but does not curtail the use of previous grazing areas.

The different types of land-cover change pose several challenges to people in East Pokot. Whereas the excessive increase in acacia stands and bush encroachment in the lowlands poses a major challenge for pastoralist strategies - an issue that the Pokot have been able to address through changes in herd composition - this problem has been of little concern to people in the highlands, many of whom have resorted to crop cultivation and agropastoralism. There, the invasive ecological spread of Dodonaea viscosa is a greater concern, but the people are dealing with it successfully because this plant is not a major obstacle to the cultivation of land (except for indications of possible soil degradation). Herders in the lowlands evade the spread of Dodonaea viscosa by no longer grazing their cattle there and have moved to the Laikipia Plateau. Although not a direct constraint on cultivation or cattle husbandry for either farming or pastoral Pokot, invasive ecological processes have contributed largely to the modification of rangelands, rendering entire patches of land unusable for livestock keepers. The result is that each year during the dry season, pastoralists are forced to graze their cattle beyond the East Pokot borders, causing serious conflicts with neighboring groups.

\section{Rainfed Maize Cultivation}

Although relatively small in overall size, amounting to a total of $8,176.14$ hectares in 2015 , the category "maize fields" shows - in relative terms - the steepest increase. This figure is especially significant given that farming did not play a role in East Pokot during the colonial period and the first decades of independence, even though the Pokot in Baringo originated from an agropastoral background, and many of their ethnic fellows in West Pokot have been exemplary (irrigation) cultivators for centuries (Beech 1911; Porter 1965; Dietz 1987; Nangulu 2009; Davies 2012). Recalling the East Pokot landscape in his memoirs, the former colonial district officer Hennings (1951: 140) described the remarkable absence of cultivation: "Throughout all this wilderness there was no sign of life, no smoke or roof or cultivated patch, except for one distant cloud of dust moving slowly above the bush, which indicated a herd of cattle going to water." Even as recently as the 1980s, those who tried to farm were ridiculed or accused of disloyalty and disrespect, although the ratio of livestock to people had been constantly falling and pastures showed signs of severe degradation (Bollig and Schulte 1999; Bollig 2006).

From 1985 to 2015 , however, the area cultivated with maize increased more than sevenfold (from $0.18 \%$ in 1985 
to $1.33 \%$ in 2015). Tangulbei and Churo, sublocations to the east of Lake Baringo and towards the Laikipia Plateau (Table 1), show the highest trends of maize cultivation, ranging from 95.76 ha to $1,622.25$ ha and from 490.77 ha to $2,167.56$ ha, respectively. Given the average size of a maize field of less than one acre (approximately $0.4 \mathrm{ha}$ ) and the lack of mechanization in most areas, the extent of land conversion is impressive. This steep increase in cultivation is a result not of in-migrating agriculturalists or of a growing market for maize as a cash crop but solely of a transition in livelihood strategies among (former) specialized pastoralists (Greiner and Mwaka 2016). Data from a recent household survey in Tiaty East $(N=361)$ reveal that - based on households claiming to have either actively cultivated or fallow land - approximately $67 \%$ of all households were actively involved in cultivation (Nshakira-Rukundo et al. 2019). Possession of livestock in Tiaty is distributed disproportionately, according to this survey, pointing to increasing stratification (Greiner et al. 2021). Almost one-third of all households (28.8\%; $n=104$ of 361 ) claimed to be in possession of less than one tropical livestock unit (TLU), which is less than one head of cattle, ${ }^{6}$ whereas the average TLU/household is 10.2 (median TLU/household is 3). While a large fraction of the population manages with little or no livestock, the richest $10 \%$ of respondents own $59.1 \%$ of the livestock (of the total TLUs). However, the thrust towards agricultural engagement comes from poor as well as rich households.

The shift towards rainfed maize cultivation first emerged with the massive droughts of the 1980s. After German Agro Action (Welthungerhilfe), together with the Kenya Freedom from Hunger Council, implemented demonstration fields for rainfed agriculture and instructed pastoralists in farming as a famine relief measure, cultivation began on a small scale in a few highland areas. Unfortunately, little was documented at this time, but a 1988 project evaluation report confirms that "after completion of the programme 1985/86 most of the communal plots were abandoned and reverted to fallow bushland" (Wirth 1988: 11). This is clearly reflected in the data collected by Basukala et al. (2019a, b): the increase in land cultivated with maize from 1985 to 1990 was followed by a drop of almost $50 \%$. Only around 2000 and afterwards did farming take off on a large scale. Bollig (2006) suggests that the time around the change of the millennium was a turning point, with massive drought and widespread malnourishment in children that coincided with steeply increasing school enrollment rates. Many children started schooling

\footnotetext{
6 TLU calculations are based on the figures indicated by Galvin and Little (1999): $1 \mathrm{camel}=1.25 \mathrm{TLU}$, cattle $=1.0 \mathrm{TLU}$, and goat $/$ sheep $=0.125$ TLU. Other authors use slightly different conversion factors (see, e.g., Mcpeak and Little 2005). For reasons of comparability, we decided to retain the values used in other case studies in East Pokot (e.g., Österle 2008).
}

to profit from school feeding programs during the 1999/2000 droughts. After then president Mwai Kibaki introduced free primary education in 2002, many stayed on, and enrollment rates increased further.

This time, the area cultivated with maize almost quintupled (from 1995 to 2000), and it continued to grow rapidly from then on. These figures are consistent with ethnographic data on the spread of cultivation and related conflicts in land tenure stemming, among others, from the in-migration of lowland Pokot to the arable highlands (Greiner 2016, 2017). Our ethnographic data further confirm a clear relation between school enrollment, sedentarization, and cultivation. Between 2007 and 2011, the number of primary schools in what is now Tiaty increased from 34 to 100 (Bollig et al. 2014). The educational background of children from pastoral and agropastoral households, however, varies widely. Two 2015 surveys reported that only $25 \%$ of pastoral households had at least one child in primary school, compared to $91.7 \%$ of agropastoral households. Similarly, schooling differs among adults. Approximately 5\% in the pastoral context had a minimal primary school education, compared to $45 \%$ in the agropastoral context, of whom almost half had a secondary education or higher education.

Elsewhere, we explore the relations between these fundamental land-use changes and the growing importance of formal education, the influence of Christian churches, and the high demographic growth rates in more detail (Bollig et al. 2014; Greiner and Mwaka 2016). Cultivation, however, is not spread evenly across the area. It concentrates in places that are ecologically suitable for farming, most notably in highland valley bottoms that benefit from run-off water, near riverbeds, and in alluvial fans. These areas are concentrated in the highlands at the eastern fringes of the Pokot territory (Greiner et al. 2013). Subsequent field visits, however, suggest that maize cultivation also continues to spread to areas that were previously deemed unfit for agriculture. How far this spread is related to the cumulative increase in rainfall since 2003 (see Kiage and Douglas 2020; Petek-Sargeant and Lane 2021) - and concomitantly to climate change - is a question yet to be explored.

\section{Fragmentation of Pastoral Drylands}

The conditions for pastoral land use are becoming increasingly difficult due to progressive fragmentation processes. By fragmentation, we refer to the dissection of formerly contiguous land areas due to changes in land use or land cover. Massive vegetation changes over vast stretches of land and the transformation of parcels of land to fields and fallows are making the character of the landscape progressively discontinuous. Consequently, pasture areas are decreasing, due either to a change in quality (modification) 


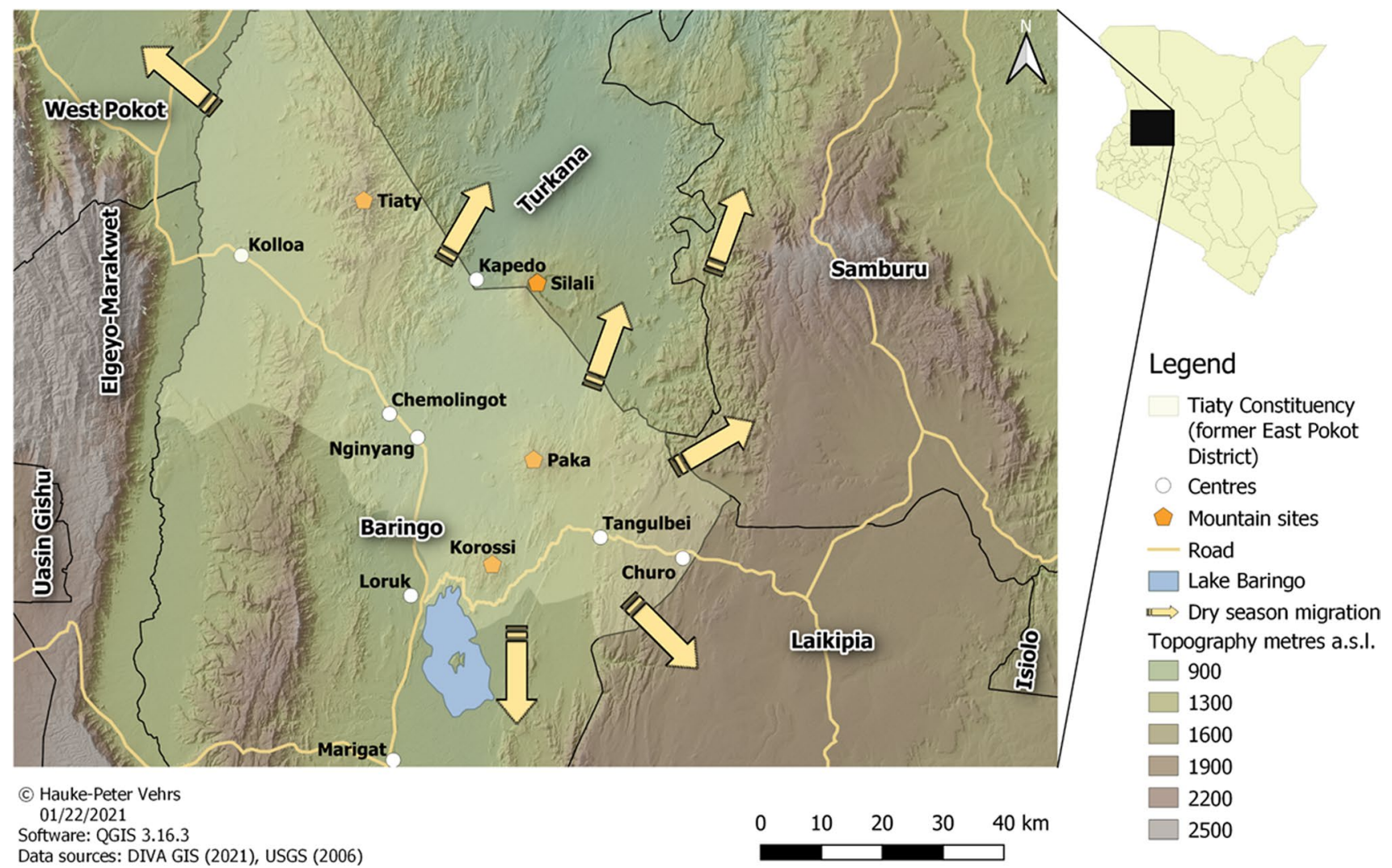

Fig. 2 Expansion of herding outside Tiaty Constituency

or "a direct change in the composition of the elements" that Reid et al. (2004: 172) attributed to loss or conversion. The fragmentation process that we describe thus does not relate to the global fragmentation of habitat into "spatially isolated parts" (Hobbs et al. 2008: 776). Rather, it refers to a broader notion of "changes in spatial patterns of the habitat" (Reid et al. 2004: 171ff). It is furthermore informed by a perspective on pastoral drylands in which rangelands are increasingly reduced and access to pastures is altered by other forms of land use, such as farming, conservation, or infrastructure projects (Galvin 2009; Reid et al. 2004; Reid et al. 2014). We show here that the loss of access due to bush encroachment - whether invasive, localized, and rapid or incremental and wide-ranging - is accelerating fragmentation. Both processes, farming and bush encroachment, necessitate altered mobility patterns (and occasionally also the migration of cattle herds out of the area) as livestock herds need to evade dense bushland as much as they need to

\footnotetext{
${ }^{7}$ Livestock data for Baringo County need to be examined with caution. Whereas Österle (2008) estimates the small stock population at the turn of the millennium at approximately 680,000 , moderate projections suggest that the population is between 310,000 and 470,000 (Vehrs forthcoming). However, there is little doubt that overall, small stock numbers have increased significantly in recent decades.
}

circumnavigate farmlands. The previously wide and freely accessible pastoral rangelands are now dotted with small and large patches of land that are inaccessible and need to be avoided.

Cattle husbandry in particular is facing multiple challenges. The decline of the grass-bush savannah has reduced the opportunities for cattle to graze in the lowlands of East Pokot and has also increased pressure on those retreat areas that have long been considered dry-season forage storage - the montane areas within the Rift Valley where the last high-quality grazing grounds exist. These areas, however, are also those in which - due to better edaphic and climatic conditions - maize cultivation has spread the most (Greiner et al. 2013).

Strong population growth and falling TLU/cap figures have contributed to this trend. Österle (2008: 84) reports an overall TLU/cap rate of 3.3. Data from our recent household survey suggest a rate of 1.5 . The reaction to the scarcity of grazing resources is differentiated: most households have become sedentary in the past 20 years. Many now combine market-oriented production of small stock (goats and sheep) with maize cultivation and other forms of income diversification. The steep increase in goat production - Österle (2008) suggests a fivefold increase from 1988 to $2005^{7}$ - can be attributed to not only the better conditions for browsers 
brought about by bush encroachment but also market incentives and improved market infrastructures. In the past years, an average of approximately 900 goats are sold on the weekly market days in Nginyang, the most important livestock market of the region. This figure reveals the value of goats to the local livestock economy, particularly in comparison to the declining economic importance of cattle (Österle 2008): an average of fewer than 50 cattle are sold on market days in Nginyang.

Major conflicts between Pokot herders and Pokot farmers appear to be rare in East Pokot, although violent conflicts habitually still take place among neighboring pastoralist groups. The reason is partly that herders no longer stay in the area but move through and continue towards the Laikipia Plateau, where better, but also highly contested, pastures are to be found (Bond and Mkutu 2018; Gravesen et al. 2019; Gravesen 2021). The invasion of the Laikipia Plateau in early 2017 is a dramatic illustration of this process. Approximately 10,000 herders, many armed with automatic guns, entered the expansive plateau and outgunned resident farmers as well as security forces. This area, which borders East Pokot and Samburu, was Maasai land before British colonialists evicted the pastoralists in 1904, turning it into what became the "White Highlands." The invaders, mostly Pokot and Samburu, drove over 135,000 cattle and up to 200,000 sheep and goats into wildlife conservancies, Maasai group ranches, smallholdings, and other private property, killing wildlife, including elephants, giraffes, zebras, and lions, and displacing approximately 10,000 people (Cruise and van der Zee 2017). The invasions are believed to have been politically orchestrated or at least fostered in the run-up to the 2017 elections, and they coincided with an extended drought that plagued Northern Kenya from November 2016 onwards (Cattle Barons 2017). Similar dynamics of expansion into Turkana and Samburu Counties as well as into the Baringo wetlands (e.g., towards Arabal; see Fig. 2) are taking place.

\section{Concluding Discussion: Shifting Socioecological Frontiers}

Transition to farming as an alternative or addition to livestock rearing is not new in the East African rangelands (Anderson 1988; Little 1992). Changes in recent decades, however, seem to be unprecedented and point to more fundamental processes of de-pastoralization (Caravani 2018) and increasing intensification of land use (Greiner and Mwaka 2016). Similar processes, including the transition to dryland cultivation, are reported for the Rendille and Ariaal (Smith 1999; Fratkin 2013), Borana (Desta and Coppock 2004; Homann et al. 2008), Samburu (Lesorogol 2008), Maasai (McCabe et al. 2010), Turkana (Campbell et al. 1999), Orma (Ensminger 1992), and other peoples. This implies a shift towards a situation in which land has emerged as a key resource, leading to increasing processes of endogenous reevaluation and commodification. In recent years, these endogenous dynamics have additionally overlapped with and reinforced the processes of land reevaluation brought about by the advance of the extractive frontier into the East African drylands (Mosley and Watson 2016; Lind et al. 2020b).

We hold that many cases of agrarian transitions such as those in the data presented here call into question simple, Malthusian-style narratives of herder-farmer resource competition. Such assumptions, implicitly and sometimes explicitly, suggest that we are dealing with two supposedly different antagonistic groups: pastoralists and (immigrant) peasants (Babiker 2001). This view is epitomized, for example, in Paul Spencer's Pastoral Continuum. "Nomadic pastoralists," Spencer (1998: 216) warns, "are edged away from their more dependable grasslands - their dry-season grazing - by the immigrant peasants, or they face the choice of turning to subsistence farming themselves or seeking work in the settled areas." The case of East Pokot clearly suggests a more nuanced form of transformation and resource competition within a changing landscape.

We suggest that these processes are reminiscent of Kopytoff's notion of the internal African frontier (Kopytoff 1987). We hold, in line with Guyer et al. (2007), that these internal frontier dynamics should be understood as a socioecological process "of moving, getting established, settling, consolidating, struggling for specific niches in resource access" (Guyer et al. 2007: 11). Like Kopytoff's model of internal frontiers, we observe that under certain (environmental) conditions, core groups split and reassemble as new social entities. In this line, we suggest that the expansion of agriculture into previously uncultivated areas (or pastureland) can be understood as an advancing agricultural or farming frontier (Netting and Stone 1996; Lane 2004). Similarly, the pushing into and (re)colonization of other territories by those who cling to pastoralist ways of life is aptly described as a pastoral frontier (Kerven et al. 2016). Such frontiers thus emerge as deeply social processes that partly react to but also contribute to LULCCs. Habitat fragmentation accelerates the establishment of new frontiers - and is, at the same time, the material or ecological evidence of such internal frontiers.

Indeed, in analogy to Kopytoff, we may interpret the dynamics in East Pokot as a schism, with many Pokot who currently rely on more sedentary and agricultural livelihoods seeing themselves as socially distinct from their pastoral counterparts. Nonetheless, the differences are often not as clear-cut as some Pokot would like to believe (Bollig et al. 2014). Many sedentary and agricultural Pokot, for example, still own cattle they keep with their pastoral relatives. However, cultural and socio-spatial practices among the more sedentary and agricultural Pokot are increasingly distinct from 
the customs, rituals, and policies of their pastoral brethren. This process suggests that a new frontier has opened because split-offs from formerly more homogeneous groups of Pokot have started to conquer new territories at the peripheries of East Pokot and - most notably - on the Laikipia Plateau. Rather than "the intrusion of cultivators into land used by pastoralists" and a domineering over allegedly powerless livestock herders (Spencer 1998: 217), we currently observe the pastoral frontier being pushed into new territories. The difference from Kopytoff's understanding of the internal African frontier, however, is the lack of empty space, not least due to recent infrastructural developments and the eruption of old conflicts along the borders (Greiner 2016). Expansion beyond the territorial boundaries is possible only with the use of violence and at the expense of other usages and users of the land. In the case at hand - on the Laikipia Plateau - this issue concerns conservationists, resident Maasai group ranches and small-scale farming communities. At the same time, our research suggests the need to pay more attention to the processes of internal differentiation and stratification within groups that are often labeled - and sometimes reified - as pastoralists.

Funding Open Access funding enabled and organized by Projekt DEAL. This research was supported by the German Research Foundation through funding for the Collaborative Research Center "Future Rural Africa” (TRR 228).

\section{Declarations}

Ethical approval This research was carried out in accordance with the University of Cologne's Guidelines for Safeguarding Good Academic Practice and Dealing with Academic Misconduct (22 July 2011).

Conflict of interest The authors declare no conflicts of interest.

Informed consent Our informants were informed about the purpose of the study and how interviews and survey data would be used in a free, prior, and informed consent procedure.

Open Access This article is licensed under a Creative Commons Attribution 4.0 International License, which permits use, sharing, adaptation, distribution and reproduction in any medium or format, as long as you give appropriate credit to the original author(s) and the source, provide a link to the Creative Commons licence, and indicate if changes were made. The images or other third party material in this article are included in the article's Creative Commons licence, unless indicated otherwise in a credit line to the material. If material is not included in the article's Creative Commons licence and your intended use is not permitted by statutory regulation or exceeds the permitted use, you will need to obtain permission directly from the copyright holder. To view a copy of this licence, visit http://creativecommons.org/licenses/by/4.0/.

\section{References}

Abbink, Jon, Kelly Askew, Dereje Feyissa Dori, Elliot Fratkin, Echi Christina Gabbert, John G. Galaty, Shauna LaTosky,
Jean Lydall, Hussein A. Mahmoud, John Markakis, Günther Schlee, Ivo Strecker, and David Turton. 2014. Lands of the Future: transforming pastoral lands and livelihoods in eastern Africa. Working Paper 154. Edited by Max-Planck-Institut für ethnologische Forschung, MPI Working Papers. Halle.

Alvarez, Miguel, Gereon Heller, Itambo Malombe, Kennedy W. Matheka, Simon Choge, and Mathias Becker. 2019. "Classification of Prosopis juliflora invasion in the Lake Baringo basin and environmental correlations." African Journal of Ecology 57 (3):296-303. doi: https://doi.org/10.1111/aje.12601.

Anderson, David M. 1988. "Cultivating pastoralists: ecology and economy among the Il Chamus of Baringo, 1840-1980." In The Ecology of Survival: Case Studies from Northeast African History, edited by Douglas H. Johnson and David M. Anderson, 241-260. London: Lester Crook.

Anderson, David M. 2002. Eroding the Commons. The Politices of Ecology in Baringo, Kenya 1890-1963.

Anderson, David M. 2016. "The beginning of time? Evidence for catastrophic drought in Baringo in the early nineteenth century." Journal of Eastern African Studies 10 (1):45-66. doi: https://doi. org/10.1080/17531055.2015.1134532.

Babiker, Mustafa. 2001. "Resource Competition and Conflict: Herder/ Farmer or Pastoralism/Agriculture?" In African Pastoralism. Conflict, Institutions and Government, edited by M. A. Mohamed Salih, Ton Dietz and Abdel Ghaffar Mohamed Ahmed, 134-144. London: Pluto Press.

Basukala Amit Kumar, Hauke-Peter Vehrs, Michael Bollig, Clemens Greiner, and Frank Thonfeld. 2019a. Dataset: Spatial-temporal analysis of land-use and land-cover change in East Pokot Kenya. https://doi.org/10.5880/TRR228DB.1

Basukala Amit Kumar, Hauke-Peter Vehrs, Michael Bollig, Clemens Greiner, and Frank Thonfeld. 2019b. Spatial-temporal analysis of land-use and land-cover change in East Pokot Kenya. https:// doi.org/10.5880/TRR228DB.2

Becker, Mathias, Miguel Alvarez, Gereon Heller, Paul Leparmarai, Damaris Maina, Itambo Malombe, Michael Bollig, and Hauke Vehrs. 2016. "Land-use changes and the invasion dynamics of shrubs in Baringo." Journal of Eastern African Studies 10 (1):111-129.

Beech, Mervyn Worcester Howard. 1911. The Suk; their language and folklore. Oxford: Clarendon Press.

Bessems, Ilse, Dirk Verschuren, James M. Russell, Jozef Hus, Florias Mees, and Brian F. Cumming. 2008. "Palaeolimnological evidence for widespread late 18th century drought across equatorial East Africa." Palaeogeography, Palaeoclimatology, Palaeoecology 259 (2-3):107-120.

Bollig, Michael. 1992. Die Krieger der gelben Gewehre. Intra- und Interethnische Konfliktaustragung bei den Pokot Nordwestkenias. Münster: LIT.

Bollig, Michael. 2006. Risk Management in a Hazardous Environment. A Comparative Study of Two Pastoral Societies. Edited by Daniel G. Bates and Ludomir Lozny, Studies in Human Ecology and Adaption. New York: Springer.

Bollig, Michael. 2016. "Adaptive cycles in the savannah: pastoral specialization and diversification in northern Kenya." Journal of Eastern African Studies 10 (1): 21-44.

Michael Bollig, Clemens Greiner, Matthias Österle. 2014. Inscribing Identity and Agency on the Landscape: Of Pathways, Places, and the Transition of the Public Sphere in East Pokot, Kenya African Studies Review 57035578 https://doi.org/10.1017/ asr.2014.92

Bollig, Michael, and Anja Schulte. 1999. "Environmental Change and Pastoral Perceptions: Degradation and Indigenous Knowledge in Two African Pastoral Communities." Human Ecology 27 (3):493-541. 
Bollig, Michael, and Matthias Österle. 2013. "The Political Ecology of Specialisation and Diversification: Long-term Dynamics of Pastoralism in East Pokot District, Kenya." In Pastoralism in Africa. Past, Present, and Futures, edited by Michael Bollig, Michael Schnegg and Hans-Peter Wotzka, 289-315. Oxford; New York: Berghan Books.

Bond, Jennifer, and Kennedy Mkutu. 2018. "A "patchwork" for peace: institutions and activities in Kenya's northern drylands." Local Environment 23 (3): 293-315

Boone, R. B., R. T. Conant, J. Sircely, P. K. Thornton, and M. Herrero. 2018. "Climate change impacts on selected global rangeland ecosystem services." Glob Chang Biol 24 (3):1382-1393. https://doi. org/10.1111/gcb.13995.

Boonman, Josef G. 1993. East Africa's grasses and fodders: Their ecology and husbandry. Netherlands: Springer.

Brockington, Dan. 2002. Fortress conservation: the preservation of the Mkomazi Game Reserve, Tanzania. Oxford, UK: James Currey.

Campbell, Benjamin C, Paul W. Leslie, Michael A Little, Jean M. Brainard, and Michael A. Deluca. 1999. "Settled Turkana." In Turkana Herders of the Dry Savanna. Ecology and Biobehavioral Response of Nomads to an Uncertain Environment, edited by Michael A Little and Paul W. Leslie, 333-352. Oxford: Oxford University Press.

Campbell, David J., David P. Lusch, Thomas A. Smucker, and Edna E. Wangui. 2005. "Multiple Methods in the Study of Driving Forces of Land Use and Land Cover Change: A Case Study of SE Kajiado Districk, Kenya." Human Ecology 33 (6):763-794.

Caravani, Matteo. 2018. "'De-pastoralisation' in Uganda's Northeast: from livelihoods diversification to social differentiation." The Journal of Peasant Studies 46 (7):1323-1346. https://doi.org/10. 1080/03066150.2018.1517118.

Casimir, Michael J., and Aparna Rao. 1998. "Sustainable Herd Management and the Tragedy of No Man's Land: An Analysis of West Himalayan Pastures Using Remote Sensing Techniques." Human Ecology 26 (1):113-134. https://doi.org/10.1023/a: 1018701001793.

Cattle, Barons. 2017. Cattle Barons. Political Violence, Land Invasions and Forced Displacement in Kenya's Laikipia County.

Chapman, Abel. 1908. On Safari. Big-game hunting in British East Africa. With studies in bird-life. London: Edward Arnold.

Conant, Francis P. 1982. "Thorns paired, sharply recurved: Cultural controls and rangeland quality in East Africa." In Desertification and Development: Dryland Ecology in Social Perspective, edited by B. Spooner and H. S. Mann, 111-122. Academic Press.

Cruise, Adam, and Bibi van der Zee. 2017. "Armed herders invade Kenya's most important wildlife conservancy." The Guardian, February 2, 2017.

Davies, Matthew. 2012. "Some Thoughts on a 'Useable' African Archaeology: Settlement, Population and Intensive Farming among the Pokot of Northwest Kenya." African Archaeological Review 29 (4):319-353. https://doi.org/10.1007/s10437-012-9118-8.

Desta, Solomon, and D. Layne Coppock. 2004. "Pastoralism Under Pressure: Tracking System Change in Southern Ethiopia." Human Ecology 32 (4):465-486. https://doi.org/10.1023/B: HUEC.0000043516.56037.6b.

Dickinson, Francis Arthur. 1908. Big game shooting on the equator. London; New York: J. Lane.

Dietz, Ton. 1987. Pastoralists in dire straits. Survival strategies and external interventions in a semi-arid region at the Kenya/Uganda border: Western Pokot, 1900-1986, Nederlandse Geografische Studies. Amsterdam: Koninklijk Nederlands Aardrijkskundig Genootschap.

Dundas, K. R. 1911. "Notes on the fauna of Baringo District." Journal of the East Africa and Uganda Natural History Society 2 (3):63-67.
Edmondson, R. N. 1965. Quarterly Report for September 1965. edited by Baringo District Range Office. Nakuru: Nakuru National Archives: EV 6/1.

Engler, John-Oliver, David J. Abson, Robert Feller, Jan Hanspach, and Henrik von Wehrden. 2018. "A social-ecological typology of rangelands based on rainfall variability and farming type." Journal of Arid Environments 148:65-73. https://doi.org/10.1016/j. jaridenv.2017.09.009.

Ensminger, Jean. 1992. Making a Market. The Institutional Transformation of an African Society. Cambridge: Cambridge University Press.

Fratkin, Elliot. 2013. "Seeking alternative livelihoods in pastoralist areas." In Pastoralism and Development in Africa. Dynamic Change at the Margins, edited by Andy Catley, Jeremy Lind and Ian Scoones, 197-205. London: Routledge.

Gabbert, Echi Christina, Gebresenbet, Fana, Galaty, Joh G., \& Schlee, Günther (Eds.). 2021. Lands of the Future. Anthropological Perspectives on Pastoralism, Land Deals and Tropes of Modernity in Eastern Africa: Berghahn

Gabbert, Echi Christina. 2021. "Introduction. Futuremaking with Pastoralists." In Lands of the Future. Anthropological Perspectives on Pastoralism, Land Deals and Tropes of Modernity in Eastern Africa, edited by Echi Christina Gabbert, Fana Gebresenbet, John G. Galaty and Günther Schlee, 1-38. Berghahn.

Galaty, John G. 1994. "Ha(1)ving land in common: the subdivision of Maasai group ranches in Kenya." Nomadic Peoples 34/35:109-122.

Galaty, John G., and Pierre Bonte. 1991. "The Current Realities of African Pastoralists." In Herders, Warriors, and Traders. Pastoralism in Africa, edited by John G. Galaty and Pierre Bonte, 267-292. Boulder: Westview Press.

Galvin, Kathleen A. (2009). Transitions: Pastoralists Living with Change. Annual Review of Anthropology 38, 185-198.

Galvin, Kathleen A. 2021. Transformational Adaptation in Drylands. Current Opinion in Environmental Sustainability 50, 64-71.

Galvin, Kathleen A., and Peter D. Little. 1999. "Dietary Intake and Nutritional Status." In Turkana Herders of the Dry Savanna: Ecology and Biobehavioral Response of Nomads to an Uncertain Environment, edited by Paul Leslie and Michael A. Little, 125146. Oxford: Oxford University Press.

Galvin, Kathleen A., Robin S. Reid, Roy H. Behnke Jr., and Thompson N. Hobbs, eds. 2008. Fragmentation in Semi-Arid and Arid Landscapes. Consequences for Human and Natural Systems. Dordrecht: Springer.

Gravesen, Marie. L., \& Kioko, Eric. M. (2019). Cooperation in the midst of violence: land deals and cattle raids in Narok and Laikipia, Kenya. Africa, 89(3), 562-585.

Gravesen, Marie. L. (2021). The contested lands of Laikipia: Histories of claims and conflict in a Kenyan landscape. African social studies series: volume 42. Leiden: Brill.

Greiner, Clemens. 2012. "Unexpected Consequences: Wildlife Conservation and Territorial Conflict in Northern Kenya." Human Ecology 40 (3):415-425. doi: https://doi.org/10.1007/ s10745-012-9491-6.

Greiner, Clemens. 2016. "Land-use change, territorial restructuring and the economies of anticipation in a Kenyan dryland." Journal of Eastern African Studies 10 (3):530-547. https://doi.org/10.1080/ 17531055.2016 .1266197$.

Greiner, Clemens. 2017. "Pastoralism and land tenure change in Kenya: The failure of customary institutions." Development and Change 48 (1):78-97. doi: https://doi.org/10.1111/dech.12284.

Greiner, Clemens. 2020. "Negotiating access to land \& resources at the geothermal frontier in Baringo, Kenya." In Land, investment \& politics: Reconfiguring Eastern Africa's pastoral drylands, edited by Jeremy Lind, Doris Okenwa and Ian Scoones, 101-109. Woodbridge: James Currey.

Greiner, Clemens, Miguel Alvarez, and Mathias Becker. 2013. "From Cattle to Corn: Attributes of Emerging Farming Systems of For- 
mer Pastoral Nomads in East Pokot, Kenya." Society \& Natural Resources 26 (12):1478-1490. https://doi.org/10.1080/08941920. 2013.791901

Greiner, Clemens, and Innocent Mwaka. 2016. "Agricultural change at the margins: adaptation and intensification in a Kenyan dryland." Journal of Eastern African Studies 10 (1):130-149. doi: https:// doi.org/10.1080/17531055.2015.1134488.

Greiner, Clemens, Greven, David, and Klagge, Britta. 2021. "Roads to Change: Livelihoods, Land Disputes, and Anticipation of Future Developments in Rural Kenya." European Journal of Development Research. doi: https://doi.org/10.1057/s41287-021-00396-y.

Guyer, Jane I., Eric F. Lambin, Lisa Cliggett, Peter Walker, Kojo Amanor, Thomas Bassett, Elisabeth Colson, Rod Hay, Katherine Homewood, Olga Linares, Opoku Pabi, Pauline Peters, Thayer Scudder, Matthew Turner, and John Unruh. 2007. "Temporal Heterogeneity in the Study of African Land Use. Interdisciplinary Collaboration between Anthropology, Human Geography and Remote Sensing." Human Ecology 35:3-17.

Hennings, R.O. 1951. African Morning. London: Chatto \& Windus.

Hobbs, N. T., Reid, R. S, Galvin, K. A., \& Ellis, J. E. (2008). Fragmentation of Arid and Semi-Arid Ecosystems: Implications for People and Animals. In K. A. Galvin, R. S. Reid, R. H. B. Jr, \& N. T. Hobbs (Eds.), Fragmentation in Semi-Arid and Arid Landscapes: Consequences for Human and Natural Systems (pp. 25-44). Springer. https://doi.org/10.1007/978-1-4020-4906-4_2

Hobley, C. W. 1906. "Notes on the geography and people of the Baringo District of the East Africa Protectorate." The Geographical Journal 28 (5):471-481.

Homann, Sabine, Barbara Rischkowsky, Jörg Steinbach, Michael Kirk, and Evelyn Mathias. 2008. "Towards Endogenous Livestock Development: Borana Pastoralists' Responses to Environmental and Institutional Changes." Human Ecology 36 (4):503520. https://doi.org/10.1007/s10745-008-9180-7.

Jiang, Hong. 2003. "Stories Remote Sensing Images Can Tell: Integrating Remote Sensing Analysis with Ethnographic Research in the Study of Cultural Landscapes." Human Ecology 31 (2).

Kerven, Carol, Sarah Robinson, Roy Behnke, Kanysh Kushenov, and E. J. Milner-Gulland. 2016. "A pastoral frontier: From chaos to capitalism and the re-colonisation of the Kazakh rangelands." Journal of Arid Environments 127:106-119. https://doi.org/10. 1016/j.jaridenv.2015.11.003.

Kiage, Lawrence M., and Kam-biu Liu. 2009. "Palynological evidence of climate change and land degradation in the Lake Baringo area, Kenya, East Africa, since AD 1650." Palaeogeography, Palaeoclimatology, Palaeoecology 279 (1-2):60-72. https://doi.org/10. 1016/j.palaeo.2009.05.001.

Kiage, Lawrence M., and Paul Douglas. 2020. Linkages between land cover change, lake shrinkage, and sublacustrine influence determined from remote sensing of select Rift Valley Lakes in Kenya. Science of the Total Environment 709 (20). https://doi.org/10. 1016/j.scitotenv.2019.136022

Klagge, Britta, Clemens Greiner, David Greven, and Chigozie Nweke-Eze. 2020. "Cross-Scale Linkages of Centralized Electricity Generation: Geothermal Development and Investor-Community Relations in Kenya." Politics \& Governance 8 (3):211-222. https://doi.org/10. 17645/pag.v8i3.2981.

KNBS. 2019. Kenya Population and Housing Census: Volume 1: Population by County and Sub-County. Nairobi: Kenya National Bureau of Statistics (KNBS).

Kopytoff, Igor. 1987. "The Internal African Frontier: The Making of African Political Culture." In The African Frontier. The Reproduction of Traditional African Societies, edited by Igor Kopytoff, 3-84. Bloomington: Indiana University Press.

Krätli, Saverio. (2019). Pastoral Development Orientation Framework: Focus on Ethiopia. Aachen: Bischöfliches Hilfswerk Misereor e.V.
Lane, Paul. 2004. "The 'moving frontier' and the transition to food production in Kenya." Azania: Archaeological Research in Africa 39 (1):243-264. https://doi.org/10.1080/00672700409480402.

Lesorogol, Carolyn K. 2008. Contesting the commons: privatizing pastoral lands in Kenya. Ann Arbor: Michigan University Press.

Lind, J., R. Sabates-Wheeler, M. Caravani, L. B. D. Kuol, and D. M. Nightingale. 2020a. "Newly evolving pastoral and post-pastoral rangelands of Eastern Africa." Pastoralism 10 (1):24. https://doi. org/10.1186/s13570-020-00179-w.

Lind, Jeremy, Doris Okenwa, and Ian Scoones, eds. 2020b. Land, Investments \& Politics: Reconfiguring Africa's Pastoral Drylands. Woodbridge: James Currey.

Little, Peter D. 1992. The Elusive Granary. Herder, Farmer, and the State in Northern Kenya, African Studies Series. Cambridge: Cambridge University Press.

Little, Peter D. 1996. "Pastoralism, Biodiversity, and the Shaping of Savanna Landscapes in East Africa." Africa Today 66 (1):37-51.

Markakis, John. 2004. Pastoralism on the Margin. London: Minority Rights Group Int.

McCabe, J. Terrence, Paul W. Leslie, and Laura DeLuca. 2010. "Adopting Cultivation to Remain Pastoralists: The Diversification of Maasai Livelihoods in Northern Tanzania." Human Ecology 38 (3):321-334.

Mcpeak, John, and Peter D. Little. 2005. "Cursed If You Do, Cursed If You Don't." In As Pastoralists Settle: Social, Health, and Economic Consequences of Pastoral Sedentarization in Marsabit District, Kenya, edited by Elliot Fratkin and Eric Abella Roth, 87-104. Boston, MA: Springer US.

Mosley, Jason, and Elizabeth E. Watson. 2016. "Frontier transformations: development visions, spaces and processes in Northern Kenya and Southern Ethiopia." Journal of Eastern African Studies 10 (3):452-475. https://doi.org/10.1080/17531055.2016. 1266199.

Muniappan, Rangaswamy, Gadi V. P. Reddy, and Anantanarayanan Raman, eds. 2009. Biological Control of Tropical Weeds Using Arthropods. Online-Ausg ed. Cambridge: Cambridge University Press.

Nangulu, Anne Kisaka. 2009. Food security and coping mechanisms in marginal areas. The case of West Pokot, Kenya, 1920-1995. Leiden: African Studies Centre.

Netting, Robert McC, and M. Priscilla Stone. 1996. "Agro-diversity on a farming frontier: Kofyar smallholders on the Benue plains of central Nigeria." Africa 66 (1):52-70. https://doi.org/10.2307/ 1161511.

Nshakira-Rukundo, Emmanuel, David Greven, Martin Paul jr. Tabe-Ojong, Michael Bollig, Jan Börner, Peter Dannenberg, Clemens Greiner, and Thomas Heckelei. 2021. Collaborative Research Centre 228: Future Rural Africa: Baseline Household Survey (2019) - Kenya. Cologne: CRC/TRR228 Database (TRR228DB). https://doi.org/10.5880/TRR228DB.7.

Obermaier, Irmgard. 2013. "Spatio-temporal assessment of maize cultivation in East Pokot, Kenya, using multispectral RapidEye and Landsat data." Master of Science Geograpy, Geography, Rheinische Friedrich-Wilhelms-Universität Bonn.

Österle, Matthias. 2008. "From Cattle to Goats: The Transformation of East Pokot Pastoralism in Kenya." Nomadic Peoples 12 (1):81-91.

Nik Petek-Sargeant ,Paul J Lane. 2021. Weathering Climate Change in Archaeology: Conceptual Challenges and an East African Case Study Cambridge Archaeological Journal 1-18 https://doi.org/ 10.1017/s0959774321000044

Petersen, Maike, Bergmann, Christoph, Roden, Paul, \& Nüsser, Marcus. 2021. "Contextualizing land-use and land-cover change with local knowledge: a case study from Pokot Central, Kenya." Land Degradation \& Development. https://doi.org/10.1002/ldr.3961.

Porter, Philip W. 1965. "Environmental Potentials and Economic Opportunities-A Background for Cultural Adaptation." American 
Anthropologist 67 (2):409-420. https://doi.org/10.1525/aa.1965. 67.2.02a00090.

Pringle, Robert M, Todd M Palmer, Jacob R Goheen, Douglas J McCauley, and Felicia Keesing. 2011. "Ecological importance of large herbivores in the Ewaso ecosystem." Smithsonian contributions to zoology 632:43-53.

Reckers, Ute. 1992. Nomadic Pastoralists in Kenya: Human ecological aspects of the East Pokot. Issue Paper International Institute for Environment and Development (iied) Drylands Programme. London: iied.

Reid, Robin S., María E. Fernández-Giménez, and Kathleen A. Galvin. 2014. "Dynamics and Resilience of Rangelands and Pastoral Peoples Around the Globe." Annual Review of Environment and Resources 39 (1):217-242. https://doi.org/10. 1146/annurev-environ-020713-163329.

Reid, Robin S., Philip K. Thornton, and Russell L. Kruska. 2004. "Loss and fragmentation of habitat for pastoral people and wildlife in east Africa: concepts and issues." African Journal of Range \& Forage Science 21 (3):171-181. https://doi.org/ 10.2989/10220110409485849.

Saltlick, A. 1991. "Baseline Data Survey in the Nginyang and Tangulbei Divisions of Baringo District, Kenya." Unpublished manuscript: Isiolo

Shackleton, Ross T., Arne B. R. Witt, Francis M. Piroris, and Brian W. van Wilgen. 2017. "Distribution and socio-ecological impacts of the invasive alien cactus Opuntia stricta in eastern Africa." Biological Invasions 19 (8):2427-2441. https://doi.org/10.1007/ s10530-017-1453-x.

Smith, Kevin. 1999. "The Farming Alternative: Changing Age and Gender Ideology Among Pastoral Rendille and Ariaal." Nomadic Peoples 3 (2):131-146.

Sombroek, W.G., H.M.H Braun, and B.J.A. van der Pouw. 1982. Exploratory soil map and agro-climatic zone map of Kenya, 1980, scale 1:1,000,000. Nairobi: Kenya Soil Survey.
Somerville, Keith. 2016. Ivory: Power and poaching in Africa. London: Hurst \& Company.

Spencer, Paul. 1998. The Pastoral Continuum. The Marginalization of Tradition in East Africa. Oxford: Oxford University Press.

Thomson, Joseph. 1887. Through Masai Land: A Journey of Exploration Among the Snowclad Volcanic Mountains and Strange Tribes of Eastern Equatorial Africa. Being the Narrative of the Royal Geographical Society's Expedition to Mount Kenia and Lake Victoria Nyanza, 1883-1884. London: Sampson Low.

Vehrs, Hauke-Peter. 2016. "Changes in landscape vegetation, forage plant composition and herding structure in the pastoralist livelihoods of East Pokot, Kenya." Journal of Eastern African Studies 10 (1):88-110. https://doi.org/10.1080/17531055.2015.1134401.

Vehrs, Hauke-Peter. forthcoming. Environmental Challenge and Social Transformation in East Pokot, Kenya: An Historical Ecology: Submitted to James Currey.

Vehrs, Hauke-Peter, and Gereon Heller. 2017. "Fauna, Fire, and Farming: Landscape Formation over the Past 200 years in Pastoral East Pokot, Kenya." Human Ecology. https://doi.org/10.1007/ s10745-017-9926-1.

Wirth, M.K. 1988. Projectevaluation Food Security Programme III, Nginyang Division/Baringo District, Kenya. Kenya Freedom from Hunger Council Nairobi, Kenya. Deusche Welthungerhilde/ German Agro Action.

Zimmermann, Helmuth, Cliff Moran, and John Hoffmann. 2009. "Invasive cactus species (Cactaceae)." In Biological Control of Tropical Weeds Using Arthropods, edited by Rangaswamy Muniappan, Gadi V. P. Reddy and Anantanarayanan Raman, 108-129. Cambridge: Cambridge University Press.

Publisher's Note Springer Nature remains neutral with regard to jurisdictional claims in published maps and institutional affiliations. 